УДК 78.071.1(477)

DOI https://doi.org/10.31723/2524-0447-2021-32-1-7

Віталій Вікторович Болгар

ORCID: 0000-0001-6148-2072

аспірант кафедри історії української музики

та музичної фольклористики

Національної музичної академії України імені П. І. Чайковського mrbvitaliy@gmail.com

\title{
ІГОР ШАМО: МИТЕЦЬ, ЛЮДИНА, ГРОМАДЯНИН
}

Стаття присвячена видатній постаті українського музичного мистецтва - Ігорю Шамо. Творчість I. Шамо досліджено за принципом законів драми, фазами якої є пролог, епілог, розвиток, кульмінація, розв'язка. Доведено, що композиторська особистість є результатом цілісності життевого і креативного факторів. Розглянуто етапи розвитку композиторської життетворчості.

Мета роботи - розгляд феномена творчої особистості видатного українського композитора другої половини ХХ сm. Ігоря Наумовича Шамо та представлення провідних констант творчого світогляду $i$ художнього мислення композитора, багатогранність образного змісту його музичних творів. Методологія досліджсення базується на принципах комплексного міждисциплінарного підходу та засад фундаментального музикознавства, що задіює такі методи, як: акмеологічний, історико-біографічний, жанрово-стильовий та семантичний з метою системного вивчення шляху композитора до професійної $i$ творчої досконалості. Наукова новизна статті полягає у сучасному осмисленні творчої постаті та розкритті сутності композиторського акме I. Шамо. Висновки. Феномен творчої особистості I. Шамо виявляється на загальносуспільному, генетико-ментальному, психологічно-особистісному та життетворчому рівнях. Це проявилося у широті світоглядних орієнтирів композитора та опорі на патріотичні духовно-соціальні константи. Композиторська індивідуальність I. Шамо проявляється у національному сприйманні засад сюжетності, розширенні та актуалізації жанрово-стильової палітри творів, активному введенні нових виразових засобів тощо. Унікальна особистість мития $X X \mathrm{~cm}$. сформувалася на основі традиційних світоглядних орієнтирів $i$ широкого кола мистецьких та естетичних вподобань композитора. Музична спадщина I. Шамо є своєрідним віддзеркаленням його світоглядних, індивідуально-творчих і духовно-особистісних настанов.

Ключові слова: Ігор Наумович Шамо, авторське мислення, жсанрово-стильові особливості, загальносуспільний, генетико-ментальний, психологічно-особистісний та життетворчий рівні, композиторська

(C) Болгар В. В., 2021 
індивідуальність, музикознавча акмеологія, феномен творчої особиcmocmi.

Bolgar Vitalii Viktorovych, Postgraduate Student at the Department of History of Ukrainian Music and Musical Folklore of the Tchaikovsky National Academy of Music of Ukraine

Igor Shamo: artist, personality, national

The article is dedicated to the outstanding figure of Ukrainian musical art Igor Shamo. I. Shamo's creativity is studied on the principle of the laws of drama, the phases of which are prologue, epilogue, development, culmination, denouement. It is proved that the composer's personality is the result of the integrity of vital and creative factors. Stages of development of composer's life are viewed.

The purpose of the work is to consider the phenomenon of the creative personality of the outstanding Ukrainian composer of the second half of the $X X$ century - Igor Naumovich Shamo and to present the leading constants of the composer's creative worldview and artistic thought, the diversity of the figurative content of his musical works. The research methodology is based on the principles of an integrated interdisciplinary approach and the principles of fundamental musicology, engaging such methods as acmeological, historical, biographical, genre and style, semantic in order to do a systematical study the composer's path to professional and creative excellence. The scientific novelty of the article is in the modern understanding of the creative figure and the exploring the essence of the composer's acme of I. Shamo. Conclusions. The phenomenon of Igor Shamo's creative personality is proven at the public, genetic, mental, psychological and artistic levels. This finds its expression in the composer's range of worldviews and his reliance on spiritual and social constants. Igor Shamo's personality as a composer is manifested in the national perception of the principles of plot, expansion and actualization of the genre and style diversity of works, active introduction of new styles, etc. The unique personality of the twentieth century's artist was formed on the basis of traditional worldview points of reference and a wide range of artistic and aesthetic preferences of the composer. An idiomatic musical heritage of Igor Shamo is the reflection of his worldview, artistic and spiritual principles.

Key words: Igor Naumovich Shamo, original thinking, genre and style features, personality of a composer, musicological acmeology, phenomenon of a creative personality.

Актуальність теми дослідження. Видатною постаттю українського музичного мистецтва був Ігоря Шамо (1925-1982). Його багатогранна творчість проходила у руслі найпередовіших тенденцій в історії української музики другої третини $\mathrm{XX}$ сторіччя. Музичні твори I. Шамо були відбиттям художніх орієнтирів своєї епохи. Композиторське обдарування Майстра мало універсальний характер, а діапазон його творчої спадщини надзвичайно широкий - від кантат, хорової опери, симфонічних та камерно-інструментальних творів до кіномузики та естрадних солоспівів. 
На жаль, творчість Ігоря Шамо не є предметом широкої дослідницької діяльності, на яку він заслуговує. Вітчизняна бібліографія, присвячена спадщині I. Шамо, достатньою мірою різноманітна, про шо свідчать матеріали монографій, науково-популярних видань і публікацій Т. Невінчаної [8], Л. Пархоменко [11], А. Терещенко [16], у збірнику статей Наукового вісника Національної музичної академії України ім. П.І. Чайковського «Ігор Наумович Шамо. Сторінки життя та творчості», виданого до 80-річчя композитора [7], О. Батовської [2; 3]. Спогади, статті, інтерв’ю, вірші, документальні фотоматеріали, малюнки та копії висвітлюють особистість I. Шамо як композитора, творця, музиканта, людини на тлі музичного життя України у книзі «Я з Вами був і буду кожну мить», друк якої був ініційований донькою композитора Тамарою [17].

Творча особистість Ігоря Наумовича Шамо заслуговує на більш глибокі розмисли в різних аспектах як творчому, так і особистісному. Серед перспективних напрямів досліджень сучасної наукової думки визначимо теорію стильової еволюції композиторської творчості як відображення вікових змін у свідомості композитора. На нашу думку, вивченню творчої особистості українського композитора XX ст. I. Шамо та його шляху до досконалості, професійної зрілості і творчої «кульмінації» сприятиме музикологічна акмеологія, розробка якої $\epsilon$ нагальним завданням сучасного музикознавства.

Мета дослідження - розгляд феномена творчої особистості видатного українського композитора другої половини XX ст. Ігоря Наумовича Шамо та представлення провідних констант творчого світогляду і художнього мислення композитора, багатогранність образного змісту його музичних творів.

Методологія дослідження базується на принципах комплексного міждисциплінарного підходу та засад фундаментального музикознавства, що задіює такі методи, як: акмеологічний, історико-біографічний, жанрово-стильовий та семантичний 3 метою системного вивчення шляху композитора до професійної і творчої досконалості.

Наукова новизна статті полягає у сучасному осмисленні творчої постаті та розкритті сутності композиторського акме I. Шамо.

Виклад основного матеріалу. Ми живемо в такий час, коли, на жаль, спостерігається серйозне падіння інтелектуального 
рівня в особистісному вимірі. Популістські заклики керівників держави, яких ми вважали сильними, не тільки в економічному, але й політичному напрямі, 3 одного боку, а 3 іншого - бажання мас здобути все і відразу, як співається в одній пісні - «мы хотим сегодня, мы хотим сейчас», - є сьогоденними реаліями. Такий загальний стан речей викликає тривогу і наші погляди повертаються до минулого і тих особистостей, які залишили свій вагомий внесок в інтелектуальному коді своєї нації, країни.

Для нас, музикантів, завжди будуть взірцями такі творчі особистості, як Л. Ван Бетховен, Дж. Верді, Б. Сметана, Б. Бартак, Б. Бріттен, І. Стравінський, Дм. Шостакович, М. Равель та ін., а в українській музиці - М. Лисенко, О. Кошиць, М. Леонтович, Л. Ревуцький, К. Данкевич та ін. Особливе місце серед вітчизняних композиторів посідає видатна постать Бориса Миколайовича Лятошинського, якому нещодавно музична громадськість відзначала 125-річчя від дня народження. Видатний Митець, класик української музики XX століття, Вчитель, непересічна особистість, людина високих моральних та людських якостей, Б. Лятошинський виховав промінну плеяду композиторів (В. Сильвестров, I. Карабиць, С. Станкович, О. Канерштейн, М. Полоз), які нині є гордістю національної культури. Серед них ім'я Ігоря Шамо, який волею долі став учнем Б. Лятошинського.

Яка ж вона творча особистість I. Шамо, у чому криється секрет його композиторського акме?

Н. Савицька вважає композиторську особистість результатом цілісності життєвого і креативного факторів. На ії думку, розвиток композиторської життєтворчості відбувається за законами драми, фази якої: пролог, епілог, розвиток, кульмінація, розв'язка. Безумовно, ці фази зазнають нескінченних індивідуалізованих варіантів, корегують численні «біографічні сценарії [13].

Звернувшись до наукових праць знаних учених, таких як М. Мамардашвілі [5], А. Орлов [10], Н. Савицька [14], О. Самойленко [15], можна дійти висновку, що поняття особистості має такі аспекти свого виявлення - від загальносуспільного, генетико-ментального, психологічно-особистісного до конкретних фаз життєтворчості.

Спробуємо розглянути постать Ігоря Наумовича в цих чотирьох аспектах. 
Перший - загальне визначення особистості - сукупність властивостей, притаманних певній людині, що являє ії індивідуальність.

У суспільному житті I. Шамо був людиною, яка щиро любила свою Батьківщину, адже його покоління витримало всі труднощі військового часу ставши без вагань за свій рідний дім, сім'ю, батьків. Однією з провідних у творчості I. Шамо була тема патріотизму, яка знайшла яскраве втілення особливо в його пісенному доробку. Пісні «Ничего нет священнее Родины», «Баллада о братстве», «Баллада у трубачах», «Фронтовики», «Стоит над Волгою курган», «Песня мира», «Романтики», «Товарищ песня» красномовно говорять про це. У магістральній темі своєї творчості виявлялася його громадянська позиція, ставлення до життя, загострене непоказне почуття патріотизму. В одному з інтерв'ю I. Шамо стверджував: «Чим старшим я стаю, тим більше переконуюся: громадянська тема в мистецтві безмежна, невичерпна $<\ldots>$. Вдала громадянська пісня відразу входить у світ людини, тому що зачіпає у ній не якусь одну струну, а цілий оркестр почуттів і думок. I він - цей оркестр - ще довго звучить, навіть коли пісня стає минулим спогадом» [17, с. 37-38].

Твори І. Шамо, в якому би жанрі він не працював, якнайкраще віддзеркалюють свою епоху та відчуття іiі емоційної атмосфери. Цю думку влучно доповнюють слова А. Терещенко: «Він належав до трагічного, обпаленого війною покоління митців, творча доля яких складалася в перше післявоєнне десятиліття. Представники цього покоління здебільшого не були у відкритому конфлікті ані із суспільним ладом, ані з усталеною мистецькою традицією, принаймні не так активно вдавалися до іiі руйнації, як це робили на зламі 50-60-х років їхні молоді колеги. Однак талант, високі моральні настанови, відчуття естетичних запитів того часу, постійна вимогливість творчості багатьом із них забезпечили гідне місце в українській культурі, а їхнім творам - постійний інтерес слухачів» [16, с. 20].

Свою творчість композитор дарував людям протягом свого недовгого, але яскравого і наповненого життя. Ігор Наумович завоював велику популярність і любов мільйонів людей, чия музика і зараз продовжує хвилювати та знаходити відклик у серцях представників різних поколінь. 
Щодо творчої особистості I. Шамо на думку приходять слова О. Асмолова, який вважає, що «бути особистістю - це значить мати активну життєву позицію, про яку можна сказати: «на тому стою і не можу інакше. Бути особистістю - це значить здійснювати вибір, що народжується через внутрішню необхідність, вміти оцінити наслідки прийнятого рішення і тримати за них відповідь перед собою і суспільством.

Бути особистістю - це значить мати свободу вибору і нести через усе життя тягар вибору. Бути особистістю - це значить здійснити внесок у суспільство, заради якого живеш і в якому життєвий шлях індивідуальності перетворюється на історію Батьківщини, зливається з долею країни» [1, с. 363].

Другий аспект творчої особистості І. Шамо - генетико-ментальний. Індивідуально-біографічний ракурс дослідження композиторської постаті І. Шамо відіграє визначальну роль. Особистість формується вихованням, яке відіграє вирішальну роль у цьому процесі і є провідним чинником іï розвитку. За словами доньки І. Шамо Тамари, «для кожної людини іiі батьки є особливим космосом, який не тільки дає фізичне життя, але й формує емоційну сферу, духовність, моральні критерії, спадковість, яка, зрештою, втілюється в дітях і внуках» [17, с. 7].

Зі спогадів дочки I. Шамо ми дізналися про родинну легенду, яка розповідає про те, що перше слово, яке вимовив хлопчик, було «пісня». Достовірно невідомо, правда це чи ні. Але хочеться вірити, що в цій легенді був особливий знак, притаманний від природи, і який став вирішальним у подальшому виборі життєвого шляху юного композитора. Надалі саме створення музики стало сенсом життя видатного митця.

Композитор не уявляв себе поза музикою. Він вважав, що як би не складалась його доля, він усе рівно прийшов би до музики. Адже, за влучним спостереженням Т. Невінчаної, Музика «жила в ньому як дихання, без котрого гасне світ довкола. <...> Усе життя і творчість Ігоря Шамо - свідчення того, як неусвідомлений потяг до незбагненно загадкового мистецтва звуків перетворився на високу потребу духу, як 3 хаосу музичних вражень поступово зросла струнка система власного музичного мислення, як з перших невмілих дослідів народилися твори великої художньої сили і високої професійної майстерності» [17, с. 22]. 
I. Шамо був дуже обдарованою дитиною. Бабуся композитора розповідала про те, як він уже у півтора року заспівав пісню, правда, неправильно вимовляючи слова: «Ямщик, не гони солодей!». Уже в чотири роки він читав, добре малював і ліпив, мав абсолютний музичний слух, міг легко підібрати будь-яку мелодію [17, с. 9]. Не будучи музикантами, батьки композитора полюбляли не тільки слухати музику, а і співати.

Вплив на формування дитячих вражень справило місто Київ. Чудове старовинне місто з його співучою красою 3 дитинства оточувало юного композитора. Хлопця захоплювала мальовничість Києва, вигини його вулиць і пишно-зелені парки, величний Дніпро і прекрасні зелені схили. Символічно, що через роки І. Шамо створить гімн рідному місту, пісню «Як тебе не любити, Києве мій!», що стала емблемою, особливою музичною візитівкою нашої країни.

Але повернемося до біографічних фактів життєтворчості I. Шамо. Батьки були в роздумах, куди віддати сина на навчання - до вчителів живописання чи до музичної школи, але сам хлопчик надав перевагу музиці. У 1935 році І. Шамо вступив до першої української музичної спеціалізованої школи для талановитих дітей. Після іiі закінчення у 1941 році він планував далі навчатися у консерваторії. Але починається війна, батько мобілізований на фронт, а родина евакуюється до Уфи. Там I. Шамо проходить короткий піврічний термін навчання у медичному училищі, записується добровольцем на фронт у званні лейтенанта медичної служби. Надалі тема війни завжди була присутня у творчості композитора (згадаємо пісню «Фронтовики», симфонію № 3 «Пам’яті героїв, загиблих у Другій світовій війні» та ін.).

Після закінчення війни у Відні 1945 року І. Шамо познайомився зі своєю майбутньою дружиною Людмилою, а 4 квітня 1946 року у радянському посольстві Відня був зареєстрований між ними шлюб.

Рік потому молода сім'я повертається до Києва. І. Шамо вступив до консерваторії на відділення композиції в клас до видатного композитора і педагога Б.М. Лятошинського. Ті часи були важкими: зруйнований Київ, розбомблені будинки і холодні квартири, продуктові картки. I. Шамо для забезпечення сім’ї поєднує навчання з роботою.

Талант має багато граней. 3 цього часу у I. Шамо проявився талант чоловіка і талант батька, талант друга і просто 
талант як людини, до якої тягнуться, яка завжди готова прийти на допомогу.

Третій аспект якостей митця - психологічно-особистісний.

Митець часто згадував про драматичну долю режисера I. Слісаренка, якого несправедливо звинуватили у загибелі героїні фільму «Іванна» Інни Бурдюченко. Весь тюремний строк перебування режисера Ігор Наумович опікувався хворою дружиною і двома синами Слісаренка. Справжньою людиною не народжуються, iii треба виховати у собі. Бути особистістю - значить мати активну життєву позицію, свободу вибору і нести через усе життя ідеали добра, честі, краси. Адже, за влучним спостереженням О. Самойленко, «найбільш загальна й інтегративна творча функція людини - це іiі орієнтація у світі, здатність до діалогу зі світом та до самодіалогу. Крім усіх інших творчих завдань, у людини є одне постійне творчість життя, отже, творчість самої себе» [15, с. 20].

За спогадами близьких і друзів, I. Шамо завжди вражав абсолютною відсутністю снобізму - культу особистої персони. Відоме його відношення до молодих, початківців-композиторів і поетів - він залюбки надавав допомогу їм та підтримку, і не тільки професійну, але й часто практичну, кар'єрну. І. Шамо «відкрив» таких відомих нині композиторів і поетів В. Ільїна, І. Карабиця, Ю. Рибчинського, А. Демиденка. 3 цього приводу відомий український композитор Іван Карабиць говорив: «У Ігоря Наумовича була рука благословляюча, як у батюшки» [17, с. 41]. I. Шамо дуже любив та цінував друзів, які часто збирались у його домі.

Життєтворчість. Творчий шлях, як окремий вимір життєвого простору, уособлює діахронний різноспрямований вектор становлення, професійної кар'єри, іiі тривалість, темп, насиченість. «Композиторська індивідуальність, - підкреслює В. Бобровський, - визначається сполученням низки факторів - душевних властивостей митця, рис його характеру, етичних та світоглядних принципів, естетичних ідеалів, перевтілених в індивідуальному баченні світу. До цих загальнолюдських властивостей, звісно, необхідно додати i весь комплекс суто музичних схильностей - як сприйнятих від навколишнього середовища, так і вихованих у собі самим композитором» [4, с. 11].

На сучасному етапі розвитку музичної культури постать I. Шамо отримує новий резонанс у музичних колах. За сло- 
вами багатьох сучасних музикознавців, I. Шамо вважається одним із надзвичайно затребуваних композиторів української музики XX ст., бо його твори визначались не тільки високим професіоналізмом жанрів музичного мистецтва, збагачуючи багатотрепетним мелодизмом, щемом інтонаційного внутрішнього току, гармонічною взаємодією всіх структурних компонентів, природністю вислову. За спостереженням Т. Невінчаної, композиторська майстерність I. Шамо рівноцінно проявилася як у малих, так і у великих формах [8, с. 78]. Композиторське обдарування майстра мало універсальний характер, а діапазон творчої спадщини надзвичайно широкий від кантат («Співає Україна» на вірші Д. Луценка, «Ленін» на слова В. Маяковського), симфонічних творів («Фестивальна сюїта», «Молдавська поема-рапсодія»), камерно-інструментальних творів (4 квартети для струнних) до кіномузики («Як гартувалась сталь», «Матрос Чижик», «Мальва», «Командир корабля») й окремих естрадних пісень («Осіннє золото», «Києве мій») [6].

Траєкторія життєтворчості I. Шамо на всіх етапах його генетико-ментального, психологічно-особистісного та життєтворчого самоздійснення засвідчує властиве митцю безперервне тяжіння до досягнення професійних висот - від концепції до мови, від структури до змісту, від цілого до останнього слова твору. Т. Невінчана у статті «Щемлива пісня» наголошує: «Багато мрій маленького київського хлопчика, який до нестями любив музику, збулося. Він став Композитором 3 великої літери. В нього була чудова сім'я, гостинний затишний дім. Але, мабуть, так влаштоване життя, що повне щастя завжди неосяжне. Доля відпустила композитору 57 років. Людина з прекрасним почуттям гумору, добротою і веселою вдачею, він у своїй невиліковній хворобі поводився стримано і мужньо. Митець невпинно працював, розповідав мені про новий творчий задум - симфонічну драму «Уріель Акоста» $<\ldots>$. Говорив, що це зовсім відрізняється від усього, що було написано досі» [17, с. 175-176]. Життєтворча траєкторія, вибудувана I. Шамо, мала свою кульмінацію - оперу-дійство «Ятранські ігри» (1978). «Ятранські ігри»- це унікальний твір, який був написаний у руслі «нової фольклорної хвилі» i не мав аналогій у національному професійному мистецтві в плані цілісного відтворення народного театралізованого дійства. На нашу думку, саме «Ятранські ігри» співпали з висо- 
ким злетом творчого генія композитора - народження монументального опусу для хору a cappella, 3 яким пов'язане остаточне визнання розквітлого таланту композитора.

...Пройшло майже півстоліття, як зупинилось серце композитора, якому доля відвела всього 57 років. Але не перестає звучати його музика, маючи незмінний успіх у слухачів, як професіоналів, так і найширшого кола любителів. У музиці I. Шамо перш за все хвилює безпосередність емоційного сприйняття. Адже вона - про людину, іiі відчуття і переживання, про Вітчизну, якою безмежно дорожив і захищав, красу iii природи. Митець не пішов у творчості шляхом аналізу «театру зла», горя, репресій, трагедій, яких у реальному житті було чимало. Сфера образної доминати у творах I. Шамо - лірика, але в найширшому розумінні цього поняття.

Лірика через органічний зв'язок з фольклором України. Витоки іiі - в простих жанрових формулах: пісні, танці, яскравих гармоніях, камерності звукописання, відточеності формотворення.

Лірика - в демократизмі висловлювання: від жанрів пов'язаних зі словом, його поетикою. Адже починався творчий шлях І. Шамо з пісні, романсу, хору, обробки народної пісні, музики до кіно, спектаклів, програмних інструментальних опусів. Нарешті лірика як сфера образного мислення митця. Особливість обдарування I. Шамо сягала і найглибших драматичних колізій і емоцій. Але переживаючи їх у реальному житті, композитор переплавляв їх на образи глибоких ліричних сповідей. Направленість на філософський рівень узагальнень дозволяла митцеві ніби з висоти осягнути пережите, повернувши його на рівень загального філософського сенсу.

Після фінальної кульмінації у життєтворчості І. Шамо була ще й кода: у іiі межах скороминуща втіха, що була зумовлена сподіваннями на здійснення новаторських задумів у майже закінченому рукописі симфонічної драми «Уріель Акоста». Але вона змінилися прикрістю болісного прощання та усвідомленням скороминучості людського життя.

Висновки. Феномен творчої особистості І. Шамо виявляється на загальносуспільному, генетико-ментальному, психологічно-особистісному та життєтворчому рівнях. Це проявилося у широті світоглядних орієнтирів композитора та опорі на духовно-соціальні константи. Композиторська індивідуальність I. Шамо проявляється у національному сприйманні засад сюжетності, 
розширенні та актуалізації жанрово-стильової палітри творів, активному введенні нових виразових засобів тощо. Унікальна особистість митця XX ст. сформувалася на основі індивідуальних світоглядних орієнтирів і широкого кола мистецьких та естетичних уподобань композитора. Музична спадщина I. Шамо є своєрідним віддзеркаленням його жанрово-стильових, індивідуально-творчих і духовно-особистісних настанов.

Таким чином, у композиторському акме I. Шамо органічно поєднуються зовнішні (суспільно-історичні умови розвитку мистецтва) фактори та внутрішні чинники творчості. Саме такий синтез допомагає осмисленню художньої картини світу, яку Митець творив «зі своєї глибини» [12, с. 5], прихованих смислів та розумінню багатовекторних суб'єктивних мотивів новаторства.

\section{СПИСОК ЛІТЕРАТУРИ}

1. Асмолов А.Г. Психология личности: Принципы общепсихологического анализа. Москва : Смысл, 2001. 416 с.

2. Батовська О.М. Художньо-стильові орієнтири опери «Ятранські ігри» І. Шамо. Музичне мистеитво і культура : наук. вісн. Одес. держ. муз. акад. ім. А.В. Нежданової. Одеса, 2009. Вип. 10. С. 221-231.

3. Батовська О.М. Риси хорового стилю Ігоря Шамо (на матеріалі циклу «Летять журавлі»). Вісн. Львів. ун-ту. Серія «Мистецтвознавство». Львів, 2015. Вип. 16, ч. 2. С. 48-56.

4. Бобровский В.П. Тематизм как фактор музыкального мышления. Очерки. Вып. 1 / отв. ред. и автор предисл. Е.И. Чигарева. Изд. 2-е, доп. Москва : Книжный дом «ЛИБРОКОМ», 2010. 272 с.

5. Копиця М.Д. Пам'ять. Ігорь Шамо: Ескіз до портрета. Науковий вісник НМАУ ім. П.І. Чайковського, с. 4; Вип. 49. Ігорь Наумович Шамо. Сторінки життя і творчості. Київ, 2007. 218 с.

6. Мамардашвили М.К. Лекции о Прусте (психологическая топология пути). Москва : Ad Marginem, 1995. 548 с.

7. Муха А.И. Союз композиторов Украины: справочник. Киев : Музична Україна, 1978. 264 с.

8. Науковий вісник Національної музичної академії України імені П.І. Чайковського. Вип. 49: Ігор Наумович Шамо. Сторінки життя та творчості. Київ, 2007. 218 с.

9. Невенчаная Т.С. Игорь Шамо: творческие портреты украинских композиторов. Киев : Муз. Україна, 1982. 88 с.

10. Невінчана Т.С. Невтомний у пошуках. Часопис Національної музичної академії України імені П.І. Чайковського. № 2. 2015. С. 17-31.

11. Орлов А.Б. Психология личности и сущности человека: Парадигмы, проекции, практики : учебное пособие для студентов психологических факультетов вузов. Москва : Издательский центр «Академия», 2002. 272 с. 
12. Пархоменко Л.О. Українська хорова п'єса: типологія, тематизм, композиція. Київ : Наук. думка, 1979. 218 с.

13. Роменець В.А. Психологія творчості. Вид. 2-е, доп. Київ : Либідь, 2001. 288 с.

14. Савицька Н.В. Вікові аспекти композиторської життєтворчості : дис. ... д-ра мистецтвознавства : спец. 17.00.03 «Музичне мистецтво». Нац. муз. акад. ім. П.І. Чайковського. Київ, 2009. 414 с.

15. Савицька Н.В. Хронос композиторської життєтворчості : монографія. Львів. нац. муз. акад. ім. М.В. Лисенка. Львів : Сполом, 2008. $320 \mathrm{c.}$

16. Самойленко О.І. Психологія мистецтва: мистецтвознавчі проєкції : монографія. Одеса : Видавничий дім «Гельветика», 2020. 236 с.

17. Терещенко А.К. Перегортаючи сторінки творчості: 3 історії. Музика. 2005. № 3. С. 20-22.

18. Я з вами був і буду кожну мить... Спогади, статті, матеріали про композитора Ігоря Шамо / Упор. Т.I. Шамо. Київ : ГРОНО. 2006. $248 \mathrm{c}$.

\section{REFERENCES}

1. Asmolov, A.G. (2001). Psikhologiya lichnosti: Printsipy obshchepsikhologicheskogo analiza [in Russian].

2. Batovska, O.M. (2009). Khudozhno-stylovi oriientyry opery "Iatranski ihry" I. Shamo. Muzychne mystetstvo i kultura: nauk. visn. Odes. derzh. muz. akad. im. A.V. Nezhdanovoi, 221-231 [in Ukrainian].

3. Batovska, O.M. (2015). Rysy khorovoho styliu Ihoria Shamo (na materiali tsyklu "Letiat zhuravli"). Visn. Lviv. un-tu. Seriia Mystetstvoznavstvo. Vyp. 16, ch. 2, 48-56 [in Ukrainian].

4. Bobrovskiy, V.P. (2010). Tematizm kak faktor muzykal'nogo myshleniya. Ocherki. Vyp. 1 / otv. red. i avtor predisl. E.I. Chigareva. Izd. 2-e. [in Russian].

5. Kopitsa, M.D. (2007). Memory. Igor Shamo: Sketch to the portrait. Scientific bulletin of NMAU them. P.I. Tchaikovsky. P. 4. Of. 49. Igor Naumovich Shamo. Pages of life and creativity. Kyiv, 2007. $218 \mathrm{p}$.

6. Mamardashvili, M.K. (1995). Lektsii o Pruste (psikhologicheskaya topologiya puti) [in Russian].

7. Mukha, A.I. (1978). Soyuz kompozitorov Ukrainy: spravochnik [in Russian].

8. Naukovyi visnyk Natsionalnoi muzychnoi akademii Ukrainy imeni P.I. Chaikovskoho. Vyp. 49: Ihor Naumovych Shamo. Storinky zhyttia ta tvorchosti. (2007) [in Ukrainian].

9. Nevenchanaya, T.S. (1982). Igor' Shamo: tvorcheskie portrety ukrainskikh kompozitorov [in Russian].

10. Nevinchana, T.S. (2015). Nevtomnyi u poshukakh. Chasopys Natsionalnoi muzychnoi akademii Ukrainy imeni P.I. Chaikovskoho. No. 2, 17-31 [in Ukrainian]. 
11. Orlov, A.B. (2002). Psikhologiya lichnosti i sushchnosti cheloveka: Paradigmy, proektsii, praktiki: Ucheb. posobie dlya stud. psikhol. fak. vuzov [in Russian].

12. Parkhomenko, L.O. (1979). Ukrainska khorova piesa: typolohiia, tematyzm, kompozytsiia [in Ukrainian].

13. Romenets, V.A. (2001). Psykholohiia tvorchosti. Vyd. 2-e, dop. [in Ukrainian].

14. Savytska, N.V. (2009). Vikovi aspekty kompozytorskoi zhyttietvorchosti: dys. ... d-ra mystetstvoznavstva: 17.00.03 "Muzychne mystetstvo". Nats. muz. akad. im. P.I. Chaikovskoho. Kyiv [in Ukrainian].

15. Savytska, N.V. (2008). Khronos kompozytorskoi zhyttietvorchosti: monohrafiia. Lviv. nats. muz. akad. im. M.V. Lysenka [in Ukrainian].

16. Samoilenko, O.I. (2020). Psykholohiia mystetstva: mystetstvoznavchi proektsii: monohrafiia. Odesa [in Ukrainian].

17. Tereshchenko, A.K. (2005). Perehortaiuchy storinky tvorchosti: z istorii. Muzyka, No. 3, 20-22 [in Ukrainian].

18. Ia z vamy buv i budu kozhnu myt... (2006). Spohady, statti, materialy pro kompozytora Ihoria Shamo / Upor. T.I. Shamo [in Ukrainian]. 